Research Product 94-08

\title{
Evaluation of the AirLand Battle Management Advanced Technology Demonstration Prototype Version 1.2: Review of Trend Analysis and Projection Tool
}

\author{
James P. Flanagan
}

CAE-Link Corporation

Field Unit at Fort Leavenworth, Kansas Stanley M. Halpin, Chief

Manpower and Personnel Research Division Zita M. Simutis, Director

U.S. Army Research Institute for the Behavioral and Social Sciences 5001 Eisenhower Avenue, Alexandria, Virginia 22333-5600

Office, Deputy Chief of Staff for Personnel

Department of the Army

April 1994 